\title{
KISEP
}

실험적으로 유발된 중이진주종에서 Telomerase의 발현 부산대학교 의과대학 이비인후과학교실 고의경 · 이일우 · 이병주 · 노환중 · 왕수건 · 김 대희

\section{Expression of Telomerase Activity in Experimental Cholesteatoma}

\author{
Eui-Kyung Goh, MD, Il-Woo Lee, MD, Byung-Joo Lee, MD, \\ Hwan-Jung Roh, MD, Soo-Geun Wang, MD and Dae-Hee Kim, MD \\ Department of Otolaryngology, College of Medicine, Pusan National University, Busan, Korea
}

\begin{abstract}
-ABSTRACT -
Background and Objectoves : Telomerase is a marker of cell proliferation in malignant tissues and also can be expressed in benign disease such as cholesteatoma. There are two opposite opinions about the expression of telomerase in cholesteatoma. The purpose of this study is to evaluate whether telomerase is expressed in expreimentally induced cholesteatoma. Materials and Methods : Cholesteatoma was induced by ligation of EAC of ten Mongolian gerbils. The telomerase activity was detected by the telomerase repeat amplification protocol (TRAP) assay method in both cholesteatoma and normal control retroauricular skin. Results : 10 of $10(100 \%)$ cholesteatoma cases expressed telomerase activity, whereas 3 of $10(30 \%)$ retroauricular normal skin detected telomerase activity. Conclusions : The high expression of telomerase in experimentally induced cholesteatoma suggests activation of telomerase may be related to the proliferative nature of cholesteatoma as in human tissues. ( $\mathrm{J}$ Clinical Otolaryngol 2004;15:250-255)
\end{abstract}

KEY WORDS : Telomerase $\cdot$ Cholesteatoma $\cdot$ Animal experimentation.

\section{서 론}

T elomeres는 eukary otic chromosomes의 말단에 위치하는 특수화된 구조로 단순한 뉴클레오티드의 반복 되는 sequence로 구성되어 있다(T TAGG in humans). T elomeres의 주요기능은 염색체 말단을 capping하는 것인데 이것을 통해 DNA strand break에 의해 야기되 는 DNA 손상이 활성화를 막는 역할을 한다. 따라서 telo-

논문접수일 : 2004년 10월 5일

심사완료일 : 2004년 11월 23일

교신저자 : 이일우, 602- 739 부산광역시 서구 아미동 1가 부산대학교 의과대학 이비인후과학교실

전화 : (051) 240- 7536- 전송 : (051) 246- 8668

E- mail : entgate@pusan.ac.kr mere는 DNA 의 안정성을 유지한다고 할 수 있다. ${ }^{1)}$ 세 포의 노화나 분열 등에 의해 telomere의 길이가 짧아지 게 되면 mitotic clock에서처럼 세포노화나 고사를 초래 하게 된다. ${ }^{2)}$ T elomerase는 ribonucleoprotein 효소로 서 새로운 telomere 말단을 합성할 수 있다. T elomerase는 정상 체세포에서는 발현되지 않고 악성으로 변환 된 세포에서 높은 비율로 발현되는 것으로 알려져 있다. 따라서 telomerase는 악성종양의 진단 및 예후를 판단 할 수 있는 표식자로 유용하게 사용될 수 있다. ${ }^{3)}$

최근에 Belair 등 ${ }^{4)}$ 은 생리주기의 증식기와 정상상피 세포이 증식기에 telomerase가 발현되는 것을 보고하였 다. 따라서 telomerase가 악성변화보다는 세포증식의 생체표식자가 될 수 있다는 가설을 생각해 볼 수 있다. 진주종은 각화세포층의 축적으로 특징되는 질환이다. 
진주종의 원인에 대하여는 여러 가지 이론이 개발되어 왔지만 진주종형성의 가장 기본적인 기전에 대해서도 아 직까지 완전히 밝혀지지는 않고 있다. 양성질환을 알려 져 있기는 하지만 진주종이 주변 골구조를 파괴하거나 이소골의 미란이 생기고 수술후에도 자주 재발하는 것은 진주종이 종양의 성질을 가지고 있다는 것을 시사한다. 또한 진주종은 임상적특징이 종양과 유사할 뿐 아니라 세포증식율과 같은 분자생물학적 특성에 있어서도 종양 과 유사한 특성을 가지고 있다.

진주종에서 발현되는 telomerase의 특성에 관해서는 두가지 견해가 있다. 저자들은 이미 중이진주종 환자 22 명의 조직중 17 예( $77.3 \%$ ) 에서 telomerase가 발현하며 이는 정상후이개부 조직의 15 예 모두에서 발현되지 않 아 $0 \%$ ) 중이진주종에서 telomerase가 높게 발현됨을 보고한 바 있다. ${ }^{5)}$ 이에 반해 Rudolph 등흐는 29예의 진 주종 중 1예(3.4\%)에서만 telomerase가 발현되어 편 평상피암의 9 예 중 6 예 $(66.7 \%)$ 와 의의있는 차이를 보 인다고 하여 telomerase의 발현은 진주종보다는 악성세 포의 성장에 특징적인 요인이라고 하였다.

이에 저자들은 진주종에서의 telomerase 발현의 양상 을 알아보기 위한 단계의 일환으로 gerbil에서 실험적으 로 유도된 진주종에서 telomerase의 발현양상을 대조 군과 비교하여 보았다.

\section{대상 및 방법}

\section{연구대상}

체중 65 70 g인 10마리의 Mongolian gerbils를 대
상으로 하였다. Ketamine(40 mg/kg) 과 Rumpun(8 $\mathrm{mg} / \mathrm{kg}$ ) 을 각각 복강내 주사하여 마취하고 우측 이개 뒤 쪽에 곡선의 절개선을 넣어 4 0 silk로 봉합하여 진주 종을 유도하였다. 반대편 귀의 피부를 대조군으로 사용 하였다. 3 개월후 봉합한 외이도를 열어 형성된 진주종을 확인하고 telomerase 분석을 시행하였다.

\section{연구방법}

TRAP법에 의한 telomerase 활성 측정 및 결과 분석

T elomerase 활성은 $\mathrm{Kim}$ 등 $^{7)}$ 에 의한 T RAP assay 를 이용한 TRAPEZETM T elomerase Detection Kit (Oncor Co., USA) 를 사용하여 측정과 분석을 시행하였 다Fig. 1). 실험 과정은 제작사의 지침에 따라 조직 추 출, primer에 방사선 동위원소 부착, T RAP 반응, polyacrylamide gel 전기영동, phosphorimager에 의한 결 과 분석 등의 과정으로 실시하되 다음과 같이 일부 변경 하였다.

조직 추출 단계는 보관중인 조직을 해동하는 즉시 얼 음에 담아 $4^{\circ} \mathrm{C}$ 를 유지하면서 모든 조작을 실시하였다. 50 100 mg의 조직을 microcentrifuge tube에 넣고 $100 \mu$ l의 1× CHAPS lysis buffer $(10 \mathrm{mM}$ T ris- $\mathrm{HCl}$, $\mathrm{pH} 7.5,1 \mathrm{mM} \mathrm{MgCl} 2,1 \mathrm{mM}$ EGT A, $0.1 \mathrm{mM}$ benza midine, $5 \mathrm{mM} \beta$ - mercaptoethanol, 0.5\% CHAPS, $10 \%$ Gly cerol) 를 첨가하여 예리한 가위로 잘게 자르고, 멸균된 일회용 pestle을 장착한 Pellet pestle motor (Kontes Co., USA) 가 부착된 세포 파쇄기를 이용하여 약 10초간 세포를 파쇄시켜 균질액을 만들었다. 조직

Fig. 1. TRAP assay.


균질액을 30분간 얼음에 둔 후, 5417R microcentrifuge(Eppendorf Co., Germany) 로 $4^{\circ} \mathrm{C}$ 를 유지하면서 $12,000 \times \mathrm{g}$ 에서 20 분간 원침하였다. 상층액 약 $80 \mu$ I를 새 tube에 옮겨 모아서 단백질 농도 측정 kit(Biorad Co., U.S.A.) 로 정량 측정 한 뒤 $1 \times$ CHAPS ly sis buffer로 희석하여 $1 \mu \mathrm{I} / \mu$ 가 되도록 하였다.

T RAP 반응에 사용될 TS primer(5' - AAT CCGT CGAGCAGAGT T - 3' ) 의 5' - 말단 labeling은 다음 과 같이 실시하였다. $20 \mu$ I의 반응액은 $\mathrm{Y}-{ }^{32} \mathrm{P}$ - ATP ( $3000 \mathrm{Ci} / \mathrm{mmol}, 10 \mathrm{uCi} / \mathrm{ml}$ ) $2.5 \mu \mathrm{l}$, T S primer 10.0 $\mu \mathrm{I}, 10 \times$ kinase buffer $2.0 \mu \mathrm{I}$, T 4 polynucleotide kinase $(10$ units $\mu$ I) $0.5 \mu$ I 및 증류수 $5.0 \mu$ I로 구성 되게 하였다. 이 반응액을 $37^{\circ} \mathrm{C}$ 에서 20 분간 반응시킨 후 $85^{\circ} \mathrm{C}$ 에서 5 분간 가열하여 효소를 불활성시켜 반응 을 중지시킨 후 $4^{\circ} \mathrm{C}$ 에 보관하였다.

TRAP 반응은 $2 \mu \mathrm{g}$ 의 단백질이 $25 \mu$ I의 반응액에 서 반응하도록 조성을 맞추되 시료를 제외한 모든 반응 액의 성분들은 함께 섞어서 분주함으로써 각 반응 검체 간에 반응액 조성의 차이가 없도록 하였다. 각 반응액은 10× TRAP buffer(200 mM T ris- $\mathrm{HCl}, \mathrm{pH}$ 8.3, 15 $\mathrm{mM} \mathrm{MgCl} 2,630 \mathrm{mM} \mathrm{KCl}, 0.5 \%$ T ween 20, $10 \mathrm{mM}$ EGT A, 0.1\% BSA) $2.5 \mu \mathrm{l}, 50 \times$ dNTPs $\operatorname{Mix}(25 \mathrm{mM}$ each dATP, dT TP, dGTP and dCTP) $0.5 \mu \mathrm{l},{ }^{32} \mathrm{P}$ TS primer $1 \mu$ I, T RAP primer mix(RP primer, K1 primer, T SK1 template) $0.5 \mu \mathrm{I}, \mathrm{T}$ aq polymerase( 5 units/ $\mu$ I, T akara Co., Japan) $0.2 \mu$ I 및 증류수 18.3 $\mu$ I와 검체( $1 \mu \mathrm{g} / \mu \mathrm{g}) 2 \mu$ I로 구성되어 총 $25 \mu$ 가 되 게 하였다. 고온에서 반응 도중에 증발을 방지하기 위하 여 반응액에 mimeral oil $20 \mu$ l을 중층하였다. 반응액은 PCR heating block(Mastercycler 5330, Eppendorf Co., Germany)에서 $30^{\circ} \mathrm{C}$ 에 30 분간 반응시켜 검체 속 에 포함되어 있다고 생각되는 telomerase가 반응하도록 한 후 $94^{\circ} \mathrm{C}$ 에서 30 초간 가열하여 반응을 중지시킨 다음 $94^{\circ} \mathrm{C}$ 에서 30 초, $60^{\circ} \mathrm{C}$ 에서 30 초를 한 단위로 하는 증폭 반응을 30회 반복하였다. 그리고 증폭된 산물은 전기영 동시까지 $4^{\circ} \mathrm{C}$ 에 보관하였다.

반응액의 10 분의 1 에 해당하는 loading dy e( $0.25 \%$ bromophenol blue, 0.25\% xylene cyanol, $50 \%$ glycerol, 50 mM EDT A, pH 8.0) 를 섞어서 12.5\% polyacrly amide gel(acry lamide : bis- acry lamide=19: 1) 과 $0.25 \times \mathrm{TBE}$ buffer에서 $20 \mathrm{~V}$ 의 일정전압으로 3 시간 분리하였다. 그후 gel을 건조시켜서 autoradiography 를 시행하거나 phosphorimager(Molecular Dynamics Co., USA) 로 화상 분석을 실시하여 결과를 분 석하였다. 모든 TRAP 반응액에는 PCR 반응시 T aq polymerase 억제제의 존재 여부를 확인하기 위한 내부 표준 기질이 포함되어 있으므로, 검체로서 10x CHAPS lysis buffer만 사용한 음성 반응액에서와 같이 $36 \mathrm{bp}$ 의 band만이 보이는 경우는 음성으로 판정하고, $36 \mathrm{bp}$ 뿐만 아니라 $50,56,62,68$ 등의 $6 \mathrm{bp}$ 단위로 길어지

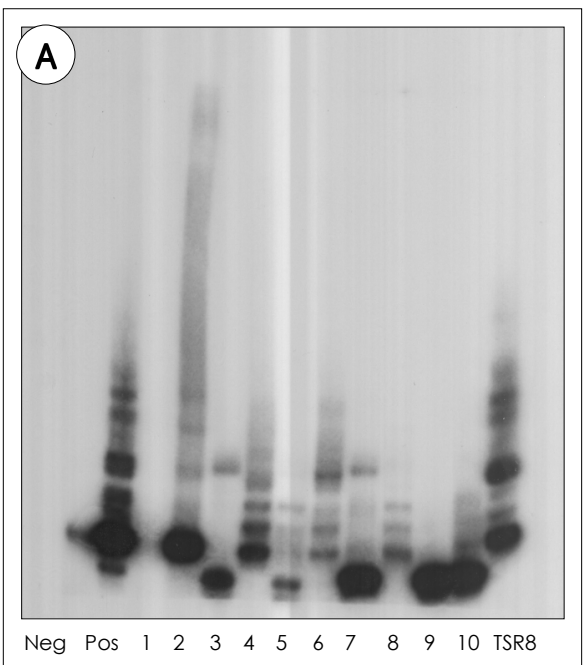

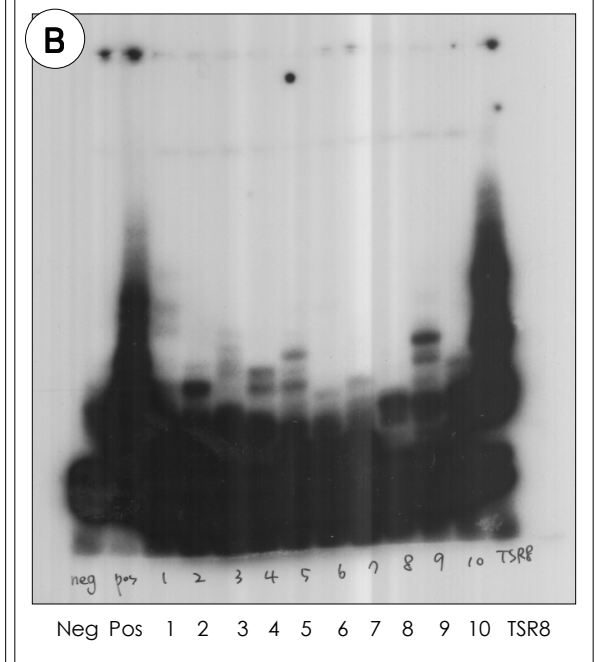

Fig. 2. Telomerase expression in expreimentally induced cholesteatoma. A : control group, Three of 10 (No. 4, 6, and 8) showed telomerase activity. B : cholesteatoma group. Ten of 10 expressed telomerase activity. 
는 TRAP 산물이 함께 나타나야만 양성으로 판정하여 검체에 telomerase가 있는 경우로 해석하였다. 모든 검 체에서 $85^{\circ} \mathrm{C}$ 에서 5 분간 가열하거나 RNase를 전처치 한 후 TRAP 반응을 실시한 결과와 비교하여 차이를 각 검체에서의 순수한 telomerase 활성을 반영하는 것 으로 판단하였다.

\section{결 과}

실험에 의해 유도된 진주종에서 telomerase 발현은 총 10예 중 10예(100.0\%) 모두에서 발현되었고(Fig. 2), 정상 외이도내 피부조직은 10 예 중 3 예(30\%) 에서 양성 소견을 보였다.

\section{고 찰}

Telomere는 진핵생물의 염색체 말단에 있는 특수구 조로서 단순한 뉴클레오티드가 연속된 구조를 가진다. telomere의 기능은 염색체 말단을 모자처럼 덮어서 DNA strand가 분열되면서 발생하는 DNA 손상을 방지하는 역할을 한다. 세포의 노화나 분열이 일어남에 따라 telomere의 길이는 짧아지게 되고 이것이 감수분열에서처럼 세포의 노쇠를 촉진하게 된다. ${ }^{1)}$

그러나 정상인의 태아 신장세포에 Simian Virus 40 tumor antigen을 감염시킨 후 계속 배양하면 감염된 세 포는 분열하여 어떤 시점이 되면 대부분의 세포는 죽게 된다. 그러나 소수의 세포는 지속적으로 분열하게되는데 이런 세포에서 telomerase의 활성이 관찰되고 telomere 의 길이가 유지된다. 그리고 죽은 세포에서는 telomerase 의 활성이 관찰되지 않고, telomere의 길이도 유지되지 않는다. ${ }^{8)}$ T elomerase는 이러한 telomere 말단을 합성 하는 능력을 가진 것으로 정상적인 체세포에서는 발현되 지 않고 악성종양에서 높게 발현되어 이러한 질환의 진 단이나 예후인자로서 알려져 있다. 태 등' ${ }^{9}$ 은 두경부암 18 예 중 16 예(89\%) 에서 telomerase가 발현되는 것을 보고하였다. Cheng 등 ${ }^{10)}$ 은 비인강암 조직 중 $85 \%$ 에서 telomerase가 발현되는 것을 보고하면서 임파절 전이가 있는 경우에는 발현률이 $100 \%$ 로 임파절 전이가 없는 경우 $(60 \%)$ 에 비해 의미있게 telomerase의 발현률이
높았다고 하였다. Mutirangura 등 ${ }^{11)}$ 은 두경부암 16 예 중 14예에서 telomerase가 발현( $87.5 \%$ ) 되었고, 구강 의 전 암 병변인 구강 백반증 및 적색반(erythroplakia) 에서는 $38.5 \%$ 에서 발현된다고 하였다. 그리고 조직학 적으로 과형성( hy perplasia) 에서 보다 이형성( dy splasia) 에서 활성이 약 3 배정도 증가되어 있다고 하였다. $\mathrm{Ka}$ nnan 등 ${ }^{12)}$ 은 구강암 및 구강 백반증 중 $75 \%$ 에서 telomerase가 발현되었으며 정상적인 구강 점막에서도 telomerase가 발현된다고 하였다. 김 등흐는 후두 유두종 의 telomerase 활성에 대한 연구에서 후두유두종 8예 중에서 7 예에서 활성이 있었다고 보고하였다. 이 또한 암이 아닌 조직에서 telomerase가 발현된 것이다.

또한 Kyo 등 ${ }^{14)}$ 은 월경 주기에 따라 정상적인 자궁내 막의 telomerase의 활성을 조사하면서 증식기(proliferative phase)에 telomerase 활성이 95\% 로 증가하지 만 분비기(secretory phase)에는 발현이 $42 \%$ 로 감소 한다고 보고하였다. 최근 Belair 등 ${ }^{4)}$ 과 $\mathrm{Kyo}$ 등 $^{14)}$ 의 연 구 결과 telomerase가 정상세포에서 암세포로의 형질변 환의 표식자 이라기보다는 세포의 증식능에 대한 표식자 라고 생각되며 이러한 결과는 본 연구와도 일치하는 소 견이다. 즉, 양성질환 중에서는 생리주기중 증식기에 발 현이 되고 정상상피나 비뇨기상피의 배양에서도 발현되 어 telomerase는 세포가 악성으로 변환하는 지표라기보 다는 세포증식의 생체지표로 생각되어질 수 있다.

진주종은 PCNA, EGF, EGFR 등을 이용한 연구에서 기저층 및 기저층 직 상부에서 증식능이 매우 증가되어 있다. ${ }^{15) 16)}$ Shinoda 등 $^{17)}$ 의 연구에 의하면 세포의 증식 능을 의미하는 c- jun 유전자가 진주종의 기저층 및 기 저층직 상부에서 발현되나 과립층에서는 발현되지 않는 다. 세포의 증식능을 억제하는 기능을 가진 wide type p53은 기저층에서는 발현되지 않고 단지 과립층에서만 발현되었다고 하면서 이러한 과립층에서 증가된 wide type p53이 진주종의 apoptosis와 연관성이 있다고 하 였다. 박 등 ${ }^{18)}$ 은 진주종 상피에서 Fas의 발현 및 apoptosis 반응을 나타내는 세포가 정상 세포에 비해 월등히 증가하는 것을 보고하였다. 즉 진주종 상피는 기저층에 계속적인 세포의 과증식이 있으면서 과증식한 세포의 상 층부에서는 apoptosis가 활발하여 케라틴을 축적시킨는 것을 특징으로 하고 있다. 
Holly 등 $^{19)}$ 은 진주종의 증식능이 증가되어 있고 c$\mathrm{myc}$ 암 유발유전자가 세포의 분화 및 성장에 연관성이 많다는 것에 착안하여 진주종에 c- myc 암 유발 유전자 산물이 증가된 것을 보고하였다. 조직학적으로 암세포의 변화가 없는 진주종에서 telomerase가 비교적 높은 비 율로 발현되었다는 것은 telomerase의 발현이 암세포로 의 형질 변화의 표식자라기 보다도 세포 증식의 표식자 라는 Belair 등의 주 주장과 일치하는 것이다.

진주종에서의 telomerase의 발현에 관한 임상연구는 현재까지 두가지의 상반된 결과가 보고되고 있다. 진주 종의 특성이 악성종양과 유사하다는 점에 착안하여 연구 한 Goh 등희 의 결과에 따르면 중이진주종에서 정상피부 조직에 비해 telomerase가 더 높게 발현되어 이것이 정 상조직과는 다른 진주종의 성질에 기여한다고 하였다. 반 면 Rudolph 등은 편평상피암에 비해 진주종에서 telomerase는 발현빈도도 낮고 활성도도 낮다고 하였다. 이 러한 양상은 편평상피암보다 진주종에서 apoptosis가 현 저하게 낮게 측정되는 것과 일치하며 이러한 telomerase 의 부재가 진주종의 성장을 억제하여 진주종이 악성종 양과는 다른 특징을 갖게 한다고 주장하였다. Kojima 등 $^{20)}$ 은 telomerase는 선천성진주종에서는 발현되지 않 고 후천성진주종과 정상피부조직에서 조금 발현된다고 하여 이전의 두 연구와는 전혀 다른 결과를 보고하였다. 선천성진주종에서의 telomere길이가 후천성 혹은 정상 피부조직에서보다 짧으며, 선천성진주종에서 telomerase 가 발현되지 않는 것은 선천성 진주종이 퇴화한 태아조 직에서 기원한다는 이론을 뒷받침한다고 하였다.

본 연구의 결과에 의하면 실험적으로 유발된 진주종 에서 telomerase가 정상외이도 조직보다 높게 발현하여 후천선 진주종 22예를 보고한 이전의 연구결과와도 일 치하였다. 이는 앞서 언급한데로 악성종양에서의 경우처 럼 진주종에서도 telomerase가 높게 발현되어 진주종 의 증식능을 유발시키는 원인의 하나로 생각할 수 있다. 따라서 telomerase는 진주종에서 세포의 증식에 관계하 는 하나의 인자로 작용한다고 할 수 있다.

\section{결 론}

암세포에서 높게 발현되는 telomerase의 발현이 진
주종에서 어떻게 발현되는지에 대하여는 크게 두가지 견해가 있다. 즉 진주종과 같이 증식성이 높은 경우에도 telomerase의 발현이 증가한다는 것은 저자들이 이전의 연구에서 밝힌바가 있고 반면 진주종과 편평상피세포암 중 암에서 높게 발현되어 종양의 표식자로서 중요하다 는 주장도 있다.

동물실험을 통한 본 연구의 결과 진주종에서 정상조직 에 비하여 telomerase의 발현은 증가되는 것을 알 수 있었다. 이는 telomerase가 진주종과 같이 증식성을 가 진 질환에서 증가한다는 이전의 연구결과를 뒷받침하는 것으로 telomerase는 진주종에서 증식능의 표식자 중 하나로 이용될 수 있음을 뜻한다.

중심 단어 : T elomerase. 진주종. 동물실험.

\section{REFERENCES}

1) Blackburn EH. Structure and function of telomeres. Nature 1991;350:569-73.

2) Harley CB. Telomere loss: mitotic clock or genetic time bombs. Mutat Res 1991;256:271-82.

3) Dahse R, Fiedler W, Ernst G. Telomeres and telomerase: biological and clinical importance. Clin Chem 1997;43: 708-14.

4) Belair CD, Yeager TR, Lopez PM, Reznikoff CA. Telomerase activity: a biomarker of cell proliferation, not malignant transformation. Proc Natl Acad Sci USA 1997;94: 13677-82.

5) Goh EK, Lee BJ, Wang SG, Chon KM, Kim CM. Expression of telomerase activity in cholesteatoma otitis media. The Journal of Laryngology \& Otology 2001;115:881-4.

6) Watabe-Rudolph M, Rudolph KL, Averbeck T, Buhr T, Lenarz T, Stover T. Telomerase Activity, Telomere Length, and Apoptosis: A Comparison between Acquired Cholesteatoma and Squamous Cell Carcinoma. Otology \& Neurotology 2002;23(5):793-8.

7) Kim NW, Piatyszek MA, Prowse KR, Harley CB, West MD, Ho PTL, et al. Specific association of human telomerase activity with immortal cells and cancer. Science 1994;266: 2011-5.

8) Counter C, Avilion A, LeFeuvre C, Stewart N, Greider C, Harley $\mathrm{C}$, et al. Telomere shortening associated with chromosome instability is arrested in immortal cells which express telomerase activity. EMBO J 1992;11:1921-9.

9) Tae K, Lee HS, Kim KR, Park CW, Ahn KS, Kim SK, et al. Comparison of telomerase activity in normal and head and neck cancer tissues. Korean J Otolaryngol 1996;39:1110-6.

10) Cheng RYS, Yuen PW, Nicholls JM, Wei W, Sham JST, Yang XH, et al. Telomerase activity in nasopharyngeal carcinoma. Britist J Cancer 1998;77:456-60.

11) Mutirangura A, Supiyaphun P, Trirekapan S, Sriuranpong V, Sakuntabhai A, Yenrudi S, et al. Telomerase activity in oral 
leukoplakia and head and neck squamous cell carcinoma. Cancer Res 1996;56:3530-3.

12) Kannan S, Tahara H, Yokozaki H, Mathew B, Nalinakumari KR, Nair MK, et al. Telomerase activity in premalignant and malignant lesions of human oral mucosa. Cancer Epidemiol Biomarker Prev 1997;6:413-20.

13) Kim CD, Sung MW, Hong SK, Kim KH. Telomerase activity in laryngeal papilloma. Korean J Otolaryngol 1997;40: 1384-9.

14) Kyo $S$, Takakura M, Kohama $T$, Inoue M. Telomerase activity in human endometrium. Cancer Res 1997;57:610-4.

15) Min WS, Jung HS, Park JY, Jun BH, Song GY. Immunohistochemical study on the expression of proliferative markers of the squamous epithelium of the cholesteatoma. Korean $J$ Otolaryngol 1995;38:1884-92.

16) Park CW, Jang YH, Tae K, Kim SK, Lee KC. Experimental study on TGF- $\beta$ gene ex pression in cholesteatoma. Korean J Otolaryngol 1997;40:69-75.

17) Shinoda H, Huang CC. Expressions of c-jun and p53 proteins in human middle ear cholesteatoma: relationship to kerationcyte proliferation, differentiation, and programmed cell death. Laryncoscope 1995;105:1232-37.

18) Park HJ, Park KH, Kim BH, Choung YH, Chung MH. Mechanism of apotpotic cell death in cholesteatoma epithelium. Korean J Otolaryngol 1998;41:425-9.

19) Holly A, Sittinger M, Bujia J. Immunohistochemical demonstration of c-myc oncogene product in middle ear cholesteatoma. Eur Arch Otolaryngol 1995;252:366-9.

20) Kojima H, Miyazaki H, Shiwa M, Tanaka Y, Moriyama H. Molecular biological diagnosis of congenital and acquired cholesteatoma on the basis of differences in telomere length. Laryngoscope 2001;111:867-73. 